\title{
The British Attitudes Toward European Union Project of 1975
}

\author{
Victor Chepik \\ Institute of History, Saint-Petersburg State University, Saint-Petersburg, Russian Federation
}

\section{Email address:}

victor_chepik@mail.ru

\section{To cite this article:}

Victor Chepik. The British Attitudes Toward European Union Project of 1975. History Research. Vol. 7, No. 2, 2019, pp. 38-48. doi: 10.11648/j.history.20190702.13

Received: May 17, 2019; Accepted: June 26, 2019; Published: October 16, 2019

\begin{abstract}
This paper examines the British attitudes toward the issues of the European Community movement to the next stage of integration. The author focuses on the lengthy report on European Union by the Belgian Prime Minister L. Tindemans. The author analyzes three main directions of movement toward political union. They are firstly, the issues of the common foreign policy which proved to be the main reasons for building Europe; secondly, the proposals on economic and monetary union which were the most critical in Britain; thirdly, the institutional developments which were not of a federalist nature and commented on by the British officials in a positive tone. The author argues that those points in the report which did not suit the UK interests, the British government intended to settle down during negotiations by their exception or granting of special conditions to the United Kingdom.
\end{abstract}

Keywords: L. Tindemans' Report, The European Integration, The Political Union, Common Foreign Policy, The Economic and Monetary Union, Institutional Development

\section{Introduction}

The idea of movement to a new stage of European integration was intensively discussed during the first half of 1970s. The discussions covered the spheres of politics, economic and institutes structure. All proposals were analyzed and summed up in a lengthy report by the Belgian Prime Minister L. Tindemans in 1975. The report laid the basis for further discussions on the issue of movement to the political union among the members of the European Community. The beginning of practical realization of the idea of political union in Europe could be traced back to the early 1970s. It took, however, many years for the basis of European idea be formulated and approved. L. Tindemans report became one of the stages on the way to European Union.

In the early of 1970s on the background of growth of inflation and unemployment caused by economic and currency crises, too many discussions cast doubt on the credibility and topicality of joint endeavor to pursue integration. There were opinions to be expressed concerning falls perspectives and necessity of integration policy to be continued. It was argued that the initial purposes of the
European integration had already been reached. The Europe, thanks particularly to their cohesion, had succeeded in the reconciliation between formerly hostile countries - Germany and France, the economic prosperity had been provided due to the enlarged market, the détente had taken the place of the Cold War. On the other hand, a number of internal and world problems, which were beyond the competence of the EEC institutes and which decision were not provided by the Rome Treaties, induced to continue integration by strengthening political unity which could compensate weaknesses of an individual state.

Those problems were: an inequality of incomes between individual states, limitation and an exhaustion of resources, internationalization of an economic life which put system of manufacture in even greater dependence on foreign markets. The states were not able to resist to an economic crisis alone. Therefore, transition to a new stage of integration which results would become creation of the European political and economic union was seen as the major means of solving those problems. The idea of the European Union represented itself as a "guiding light for the European countries which for years had lost the political consensus between countries on approaches and methods for promotion of integration" [29]. 
Britain's entry into EEC with its own views on promotion of integration processes has considerably complicated the coordination of approaches on construction of the political union. To date, what is not yet known is the degree to which the UK position on political union in Europe has been associated with the general understanding of that union among other members of the European Community.

The purpose of the study is to expand on the current literature by investigated, yet under-researched, issue of the British attitude towards European Union project in the middle of 1970s. The research seeks to address the following question: What was the British government position on $\mathrm{L}$. Tindenmans' suggestions in (1) foreign policy matters; (2) economic and monetary matters; (3) institutional development.

\section{Material and Methords}

To address the research question and the issues raised above, this study undertook an examination of the British government papers regarding the British policy in the European Community and the British interpretations of further integration policy proposals. Drawing on an extensive range of British-origin sources provides in-depth analysis of the research question. The key sources can be listed as follows: Report on European Union; Statements and interviews of L. Tindemans added with official comments; Conclusions of a Meeting of the Cabinet; the British government EEC White Paper of 1975; Degree of Divergence Between the Economic Performance of the United Kingdom and Other Member States; British Objectives in the European Community stated by then Secretary of State for Foreign and Commonwealth Affairs; notes by the British officials concerning Tindemans ' report.

The study uses comparative analysis method in order to gain insights into the aspects of the British government position concerning movement of the European Community towards the political union. The interdisciplinary approach was chosen to determine the factors that affected the UK attitudes.

\section{Discussions}

Literature analysis suggests that little previous research provides complete examination of L. Tindemans report on European Union and analyzes the British attitudes towards political union project of 1975. However, some studies address the British approach to the European project and Political Co-operation among members of the European Community in general terms. In 2014, Gifford published a paper in which he described some features of Britain integration policy. The author found that "in their dealing with the EC post-referendum, the Wilson-Callaghan regimes did not demonstrate any serious commitment to the European project". British governments were committed to membership on "anything more than pragmatic grounds". According to Gifford, there was no coherent European strategy being pursued that was linked to a broader British project of integration. "The pragmatic nationalist approach of the Labour governing elite implied the pursuit of exclusive and rigid conceptions of the national interest". The author asserts that while other member-states were responding to crisis "by beginning to contemplate further European integration, British governments were engaged in limiting the impact of membership". Particularly significant was "the recomposition of the shift in the balance forces in favour of international capital that was achieved through the intervention of the American dominated IMF". Ironically, such a policy fitted with the anti-European sentiments within the Labour party at the time. Gifford holds the view that any European strategy was firmly contained within the newly established parameters of the British politico-economic regime [7].

In 1996, Lee in his monograph "Aspects of British political history" emphasized the British economic problems which had resulted from the membership in the Community. The author found that the main "targets of the British government in the EU were the amount of the British contribution to the central budget, greater flexibility on monetary union, more emphasis on regional development and better trade terms for Third World countries in the Commonwealth" [12].

In 2007, Nielsen-Sikora in the article "The ideas of a European Union and a citizen's Europe: The 1975 Tindemans report and its impact on today's Europe" defined the idea of a European Union as "one of the basic ideas of European integration", as "the decisive signposts for which were already set during the early 1970s". The author analyzed the initial approaches for the Tindemans report (except Britain approach) and identified the impact of the report on EU with regard to the citizen's rights. J. Nielsen-Sikora found that 30 years after the launching of the report "the responsibility for securing a framework for the realization of a so-called "Citizen's Europe" has changed from originally being only a political-economic task to a task for the society as a whole". The author indicated that Tindemans in his report was to answer the following questions: Should the EU be the final stage of the European integration process or just a hop in history? What kind of institutions would belong to such a European Union? How was Europe going to make decisions? And finally what would be the location of Europe from an outside view? [16].

In 1992, Nuttall in his book "European Political Cooperation" identified objectives of cooperation in the sphere of foreign policy. He reported that participants were to "ensure, through regular exchanges of information and consultations, a better mutual understanding on the great international problems and strengthen their solidarity by promoting the harmonization of their views, the coordination of their positions, and, where it appears possible and desirable, common actions" [21].

The article of T. Helm, published in 2016, is of particular interest as it uncovers the subsequent period when the discussions on L. Tindemans report came to an end, while the 
results of the integration processes in Europe in the second half of 1970s proved to be shocking for the UK. The author argues that M. Thatcher came to despair of the European project which was to limit Europe's ambitions of Great Britain. T. Helm holds the view that Britain could not suppress in itself aspiration to keep the national sovereignty and reconcile itself to concentration of power at the center of a European conglomerate which "would be highly damaging and would jeopardise the objectives" Britain was seeking to achieve. Increasingly, it was believed, particularly by Tory Eurosceptics, "the original vision of a trading area had been supplanted by Franco-German ambitions for political and economic union" [8]. Thus, analyses of the identified literature illustrates that the UK government position on European Union project of 1975 has not been investigated in due course. Previous studies of Tindemans report have not dealt with the issue of British attitudes towards European Union project.

\section{Results}

The Rome Treaty establishing the EEC put the basis for movement towards the European political union. It stated that the members of the Community should be determined «to establish the foundations of an ever closer union among the European peoples» [32]. Closer union with co-operation in economic and political spheres seemed to be the best means to struggle against external and internal challenges at the early 1970s. The determination to construct a political union was confirmed at EEC summit conferences of 1972 and 1974 in Paris. As the aims and nature of European Union were not at those days clearly understood the first task of EEC governments was to decide what precisely were the scope and consequences of those choices.

The EEC Summit in Paris of 1972 had asked the Community institutions to produce a document which would have embraced "general perspective of the joint endeavor during the Union phase" by the end of 1975. The Paris Summit of December, 1974 commissioned the Belgian Prime Minister Léo Tindemans to prepare a report on European Union. It was necessary to pull various reports which had been forthcoming from the individual institutions all together to propose the next stage of integration. So, Tindemans took into account the reports drawn up by the European Parliament, the Commission of the European Communities, the Court of Justice, the Spierenburg Committee in the Netherlands as well as the opinions voiced by members of the Governments and other powerful forces in the various member states.

The political situation in the middle of 1970 s within European Community was full of contradictions. On the one hand, some politicians believed that it was particularly inappropriate to draw up a report on European Union at a time "when the European concept was passing through a crisis and the incompleted European structure was swaying" [29]. The opponents of the further integration in the face of "five million unemployed in the EEC countries alone, and inflation still running in double figures" called a report on a European political union "a time-wasting irrelevancy" [23]. On the other hand, the supporters of movement to political integration stated that "they could not imagine a better future for their country than that offered by the building of Europe. They could not conceive of doing this other than by strengthening the Community" [29].

The matter of the British referendum of 1975 and the issue of sovereignty still played a particular part in the drafting of the report. There was a thought that as soon as Britain had expressed its a positive view on membership of the European Community in June 1975, the discussion of the transfer of sovereignty, which was an essential part of integration, had to be "put in its proper perspective" [9]. Tindemans, however, made no proposals of a federalist nature. He "deliberately refused to draw up a report claiming to be, at least in part, the Constitution for the future European Union" [29]. According to Tindemans proposals were not directly related to the final phase of European development and stated the objectives and the methods whereby Europe could have been "invested with a new vitality and existed obstacles could have been overcome" [29].

In December, 1975 L. Tindemans presented the general concept of the European Union in the form of compilation of views on the political union existed at that time. In his opinion the European Union should consist of the different components as follows: (1) Members of the European Community present a united front to the outside world. (2) Members of the European Community recognize the interdependence of the economic prosperity of member states and accept the consequences of this: "a common economic and monetary policy to manage this prosperity, common policies in the industrial and agricultural sectors and on energy and research to safeguard the future". (3) European Union requires the solidarity of peoples to be effective and adequate. (4) European Union make itself felt in people's daily lives. It helps to protect their rights and to improve their life style. (5) In order to achieve these tasks European Union is given institutions with the necessary powers to determine a common, coherent and all-inclusive political view, the efficiency was needed for action, and the legitimacy was needed for democratic control. The principle of the equality of all States will continue to be respected within the Union by each State's right to participate in political decision making. (6) Like the Community European Union will have to be built gradually [27].

This set of interrelated commitments constituted the change which was the main feature of the European Union, and distinguished it from existed at that time stage of European unification. Explaining his proposals L. Tindemans wrote "I described European Union not as the definitive arrangement terminating the road towards the unification of Europe, but as a further, essential stage during which a qualitative change will take place in the relations between the Nine" [28]. The UK officials divided the content of Tindenmans report into three main fields of activity: (A) foreign policy matters, (B) economic, monetary and social 
policies, and (C) institutional matters [15].

Foreign policy matters

The issue of common foreign policy was of fundamental importance for Britain as well as for the other members of the European Community. As Tindemans claimed: "The convergence of two factors - "vulnerability and relative impotence" - meant that external relations were one of the main reasons for building Europe, and made it essential for the European Union to have an external policy" [27].

In his views common actions in foreign policy issues would provide a firm basis to protect effectively national interests of each members of the union, and allow Europe make its voice heard on international scale. "We must tend to act in common in all the main fields of our external relations whether in foreign policy, security, economic relations or development aid. Our action is aimed at defending our interests but also at using our collective strength in support of law and justice in world discussions", Tindemans stated [27]. But, neither could have been achieved without consolidating the authority and effectiveness of common institutions. That is why the Member States should also accept that the minority must rally to the views of the majority at the conclusion of a debate as well as the political obligation of the Member States in the context of political cooperation should, at all events, have been transformed into a legal one.

Tindemans saw four topics on which a common foreign policy should initially concentrate: the new world economic order, relations between Europe and the United States, security, and the crises in the immediate geographical surroundings of Europe. Regular exchanges of views on specific defense and security problems, cooperation in the manufacture of armaments and the establishment of a European armaments agency, as well as the preparation of a common policy in the event of crises in Europe and the Mediterranean area, should complete the foreign-policy picture [25].

The British views of a would-be European foreign policy had been expressed as early as 1967. The British Prime Minister H. Wilson in his Parliamentary Statement claimed "We do not see European unity as something narrow or inward-looking. Britain has her own vital links through the Commonwealth, and in other ways, with other continents. So have other European countries. Together we can ensure that Europe plays in world affairs the part which the Europe of today is not at present playing. For a Europe that fails to put forward its full economic strength will never have the political influence which I believe it could and should exert within the United Nations, within the Western Alliance, and as a means for effecting a lasting détente between East and West; and equally contributing in ever fuller measure to the solution of the world's North-South problem, to the needs of the developing world" [6].

In 1976 the British Foreign Secretary supported efforts to take common position on North-South issue, Mediterranean, Middle East problems and added by the British - East-West matters [15]. It was regarded in Britain that a general détente with the East might open up considerable opportunities for trade with the Eastern Europe. As far as foreign trade in Eastern Europe was under strict political control, West European commercial prospects would therefore have depended largely on the manner in which the political situation developed. As noted by one of the representatives of the British government as early as in 1970, "it was unrealistic to expect that we should be able to achieve a major expansion of our exports by normal commercial methods" [2].

However, according to Leo Tindemans the problem of "special relations with Eastern Europe" did not arise at that time because "the Soviet Union has not yet recognized the Common Market as such". "If I failed to refer to relations with Eastern Europe, it is because I don't really see how the type of special relationship that is needed with the Soviet Union and Eastern Europe could now be established", Tindemans said. Moreover, Tindemans argued, while Germany was seeking to normalize its relations with Poland and the Soviet Union, "Europe should not intervene in this diplomatic operation" [11].

Tindemans held the view that that the problem of special relations did arise with the United States. In 1962, Kennedy spoke of partners on a basis of equality, but the development of Europe had not allowed such equality to be established. "There is nothing to prevent us from being competitors, partners and allies at the same time, and we have economic and monetary problems that we share. That is why I propose that we study the nature of the relations that need to be established with the United States". For the West's economic and monetary problems to be resolved, there had to be agreement between the United States, Japan and Europe [11].

The US-European relations covered just about every field of world activity. For the Community to adopt a common position towards the US in all these fields meant in effect that the Community would have to adopt common positions on all sorts of questions where it did not have a common policy at that time. Nevertheless, the British officials claimed that "his suggestion puts the cart before the horse since Tindemans was only proposing a more binding commitment to reach common policies in very much narrower areas" [19].

Tindemans proposed that the European Council should delegate one of its members to enter into discussions with the United States Government. The eventual aim of the discussion seemed to be that certain principles and rules determining the content of and procedures for cooperation between Europe and the United States should be laid down. For the British this sounded "very like Dr. Kissinger' side as for the 'Year of Europe'". It was unclear for them why Tindemans thought it "necessary or, perhaps more important, any more achievable, to seek to establish "principles" and "write them down on tablets of stone" [19].

In Britain believed that the Schloss Gymnich formula had established US-EEC relations on a good footing and that there was no need to elaborate new principles. Furthermore, this would pose real problems because of the difficulties "brewing between the EEC and the US", for example, over agriculture. Consultation would have been likely to result in 
dispute and, in any case, given the differing views in the Community on agriculture, in particular, it was unlikely that the Council would have been able to agree on "one of its members sneaking for the Community". The British doubted whether it would be wise, or indeed practicable, for the European Council to delegate one of its members to talk to the United States since this could lead the Nine into the difficulties of coordinating national interests. The Gymnich formula whereby the Presidency kept in touch with the Americans was still appropriate, although Britain demanded to make sure that it functioned properly. On the Community side, therefore, it would be best simply to let the then-existed system of regular talks between the Commission and the US continue.

The difficulty for Britain arose from proposed the machinery of "Legal Commitment in Foreign Policy Questions" which provided amalgamation of Council Meetings and Political Co-operation Ministerial Meetings. Tindemans proposed to change the political commitment which was the basis of political co-operation into a legal obligation. He claimed that the main difference between the coordination of policies, as was practiced at that time, and a common external policy, which distinguished the Union, did not arise from the kind of procedure adopted or the nature of the relevant institution. It laid in the obligation to reach a common point of view. The States should undertake to define the broad guidelines for their policy within the European Council. On that basis, the Council then had the obligation to reach a common decision on specific questions. This obviously meant that "the minority must rally to the views of the majority at the conclusion of a debate" [29].

The UK was ready to make greater efforts to achieve common policies in foreign affairs, and to consult in order to achieve this. In Britain welcomed the idea that Foreign Ministers should, like Heads of Government, meet "in the Council and in the context of Political Co-operation" at the same time in order to end the distinction between Council and Political Co-operation Ministerial meetings and to consider all aspects of problems within the Council. It was only sensible to do so. But, it was something the Community`s Member States had already done. The British officials were doubtful whether it was necessary to introduce a new legal commitment to consult or for any legal instrument to merge political co-operation and Council Ministerial meetings. It could well be better for Britain to take up L. Tindemans' suggestion in a more pragmatic way by "merely intensifying the practices already grown up without seeking a juridical basis for them" [19]. Nevertheless, the UK had to agree to "rally to the majority view if we are in a minority on issues arising in these areas where our important national interests are not engaged" [19].

In his report L. Tindemans touched on the important question of European defense co-operation listed as one of the areas suggested for common EEC policies. He argued that "the security of one member necessarily affects the security of others" and "no foreign policy could disregard threats, whether actual or potential, and the ability to meet them". Security could not therefore have been left outside the scope of the European Union. Furthermore, the Conference on Security and Cooperation in Europe had shown that in matters of security, political, military, economic factors and those affecting human relations closely overlap. In any case, during the gradual development of the European Union, the Member States should solve the problems of maintaining their external security. Tindemans assured that "European Union will not be complete until it has drawn up a common defense policy" [27]. He proposed to cooperate in the manufacture of armaments with a view to reducing defense costs, and increasing European independence and the competitiveness of its industry. According to him it was necessary to initiate a common industrial policy on the manufacture of armaments within the framework of the European Union by setting up a European armaments agency. At the same time he noted that Member States were not yet ready to determine the common foreign policy without which no common defense policy was possible and was "unlikely to be able to do so in the near future".

The British position was expressed by the Foreign and Commonwealth Secretary who stated that nothing should be done which "might endanger in the slightest our major requirement of maintaining the complete confidence and support of the US for NATO". Not to worry the Americans common positions of the Nine on defense matters should not have cut across their common responsibilities within NATO or risk impairing the solidarity of the Alliance. Britain insisted that defence policy issues had to continue to be dealt with primarily in NATO. But the Nine had already shown that they were capable of coordinating policies on nonmilitary aspects of European security and should be able to continue this process in the "run-up to the CSCE review meeting in Belgrade in 1977 and also perhaps in discussing European aspects of MBFR", though they had to continue to handle this very cautiously in relation to NATO" [19].

For Britain, Tindemans' defense suggestions seemed sketchy and obscure. Despite his reference to a European armaments agency (an idea which Britain thought might have been premature) Britain found it possible to interpret them as follows "while standardization is tackled in the general framework of the Alliance, the Community should complement that effort by means of common industrial policy for the defense industries of the Nine" [19].

In Britain argued that an effective European response to American proposals for a "two-way street" in arms procurement would have required better co-ordination and probably some reorganization of the European industries concerned. Britain within the frameworks of Eurogroup was trying to organize the European end of the "two-way street" and had invited the French Government (who did not belong to the Eurogroup) to co-operate under ad hoc arrangements [13].

The reactions not only from Britain, but from the other countries of European Community caused by the section of the report on defense issues appeared surprising to Tindemans since, as it was commented later, he put forward 
no proposal on precisely that matter. He ascribed those initial reactions to the British Guardian newspaper. "The day before my report was presented to the press, it thought that it was in a position to provide a summary of my report. In this wouldbe 'summary', which was very brief, it referred four times to a common defence policy. In actual fact, in my report, I merely state that a full-scale European union has to include a common defense policy, but I immediately add that, at present, it would appear impossible to put forward any proposals on this matter" because opinions on this issue in Europe were too divergent [11].

Britain agreed with other miscellaneous suggestions in the external field of L. Tindemans such as the European identity had to be put across in international organizations as well as in multilateral relations with Canada and Japan; the Community should think harder about its relations with China and take account of Scandinavian views and keep in touch with all democratic European states [19].

In the whole, in Tindemans ' foreign policy proposals there seemed enough points that Britain could agree with. The British government welcomed them as forming "the basis of a positive contribution towards the search for the outward looking Community, speaking with one voice in the world that we have always advocated". Nevertheless, according to the British note "all of them needed further elucidation and study". Equally there were a number of suggestions which could have been taken as an acceptable basis for discussion as well as which seemed unlikely "to command themselves to Britain or other member governments" [19]. On the British assessments, all that Tindemans was proposing for the foreseeable future was an exchange of views.

\section{Economic, monetary and social policies}

The second field of activity embraced economic, monetary and social policies. This part of the report was mainly concentrated on the movement towards European Economic and Monetary Union (EMU) and was much less satisfactory for Britain. Initially, the plan of EMU was proposed at the end of 1969 and envisaged three main lines of development over two stages to end 1970-73 and 1980-84 respectively. First, harmonization of short and medium term economic policies - budgetary, fiscal and monetary. Second, harmonization of member currencies - margins, markets and management. Third, establishment of Community central authorities notably, a Community "agent" developing a Federal Reserve Fund or a European Central Bank, and a political authority to control it [24].

The long-term objectives of EMU went well beyond the full establishment of a Common Market and the formal provisions of the Treaty of Rome. The British government argued that with exchange control, uniform rates of tax on goods and companies, a unified currency (or, what comes virtually to the same thing, unalterable intra-Community exchange rates) and strong central direction of individual budgets, the economies of the members of the EMU would be as interlocked as those of the States of the USA [5]. Indeed, it could be argued that the independence of the members would have been less than that of the States, for the latter have more autonomy over their budgets, both as to size and composition, including the size of their surpluses or deficits.

It would, therefore, have been very difficult, if not impossible, for a member, by its own policies, to correct a "balance of payments" deficit which might emerge between it and the rest of the Community [5]. Overall, the EMU plan left little room for maneuver for an individual state. So, by joining the Community in 1973 Britain intended to gain "a hand in determining the final shape - and timing - of the Union" [5]. As a member of the European Community, Britain became committed to Economic and Monetary Union, endorsed by the Summit Meeting in Paris in October 1972, but as a distant goal.

L. Tindemans raised two central suggestions in his new approach to EMU. (1) "Two-speed" (or "two-tier" as it was called in British papers) progress towards EMU. Those States which were able to progress had a "duty to forge ahead", while "those States which have reasons for not progressing... do not do so" [29]. (2) The acceptance of the "snake" mechanism as the main means of achieving economic integration. The arrangement known as the "snake" envisaged that there should be a limited margin of fluctuation between currencies of member states.

In Tindemans views the Community "snake" should have continued to be consolidated as the centerpiece of monetary stability, which included key aspects of economic and monetary policy, namely "control of money supply, the extent and financing of budget deficits, control of the economy and the control of inflation, and should have a stronger Community identity than previously" [25]. There would also have been an additional flow of assistance to the "non-snake" members in order to enable them to catch the others up and to join the snake at a later stage. Britain had no doubt that such assistance might have been conditional both on the acceptance of a commitment to rejoin the "snake" and on a degree of joint decision making on economic policies.

Tindemans proposed that "non-snake" members should have a voice in decisions about the management and operation of the "snake". In theory, this might have been an improvement on the existed arrangements. But, in practice it had been unlikely that the "snake" Governments would have accepted that the decisions should be greatly influenced by the voice of those outside who were not accepting the obligations of "snake" membership.

In Britain made conclusions from Tindemans' recommendation as follows "(1) the "snake" is the appropriate method for progressing towards a final locking of parities and EMU; (2) although some countries may not be able to join the "snake" now, they should aim to do so in the future (and presumably sooner rather than later); (3) regional and industrial assistance should be given to enable nonmembers to join the "snake" and should be linked with an acceptance of "snake" obligations and of a closer alignment of internal economic and monetary policies" [13].

The heart of the problem for Britain, however, was Tindemans' proposition that "non-snake" members should 
accept "snake" membership as a goal (and probably also as a path to EMU) and that (in return) assistance should be given to them to help them rejoin the "snake". Taking the Tindemans' proposals as a whole, there was clearly a risk, that "if adopted, they could strengthen and institutionalize the already present tendency of the "snake" countries gradually to evolve into an inner core within the Community". In view of the potential political difficulties of any "two-tier" system, particularly one in which Britain should be in the second tier, it seemed fortunate the UK that "there was a general consensus among the Member States that it would be wrong in principle to "institutionalize" any arrangement of this kind" [13]. As one of the members of the European Commission from Britain noted, "the real world is described somberly and with sadness by Mr. Tindemans in his famous passage on a two-speed Community" [26].

Responding to criticisms Tindemans claimed that he sought to illustrate the section on economic and monetary union by talking about a convoy. "I tried to explain that, before setting out, everyone had to agree on a final port of destination. If, whilst under way, you notice that not all the engines are working at the same rate, you still do your utmost to reach the port of destination. And you also place escorts around the vessels whose engines are working less well in order to protect them more effectively" [11]. Therefore, what he was proposing was the exact opposite of a "two-speed Europe".

The least objectionable among the proposals mentioned above was the plan "for closer harmonization of economic policies among snake members". This could be acceptable for Britain and consistent with a "single-tier" Community. The British officials argued that if progress was to be made towards EMU, the essential priority should be the achievement of a greater degree of convergence in the performance of the economies of the Member States. The report only partly recognized the need for this and Tindemans made references to the need for transfers of resources from the more prosperous to the less prosperous regions in the Community.

Complementing their arguments the British stated that economic convergence rather than monetary arrangements should be the center-piece of progress towards EMU with presenting a convincing case that the "snake", at least in its existed form, was "unlikely to be a satisfactory instrument for promoting monetary stability in the period while efforts are concentrated on achieving convergence" [20].

According to the British officials there would be considerable dangers in accepting permanently fixed parities without full convergence of economic performance having been achieved. Britain premature attempts to retain a fixed parity might either come to an early end or lead to severe imbalance of the less prosperous regions of the Community. It was, therefore, desirable to implant the idea that there might be other and better approaches to EMU and, in particular that achievement of economic convergence should have been the main target and means of progress [20].

The economic performance figures show that Britain was well behind of the main EC countries. Despite of the fact that the British government undertook essential efforts for increasing efficiency of economy, according to statistical data the British economy in 1971/72 made a profit of $£ 75$ million, in comparison to $£ 210$ million in $1974 / 75$ [1], even on an optimistic assessment the UK economy could be convalescing well into the 1980 's, and there was no certainty that British economic performance and rate of inflation would have converged sufficiently or permanently with that of other Community partners.

Figures shows that in 1960 the United Kingdom was the richest among the countries which constituted the Nine in 1973 with the exception of Luxembourg (national income per head - converted into pounds sterling at the relevant exchange rate for the year concerned - was 453 for the United Kingdom, 424 for Germany, 429 for France, 402 for Belgium). In 1973 the United Kingdom was the third poorest in the Nine (after Italy and Ireland). National income per head 1159 for the United Kingdom, 2055 for Germany, 1769 for France, 1742 for Belgium. The United Kingdom had the lowest rate of growth of GNP in 1960-73. United Kingdom 3,3\%, EEC (9) - 5,0\%. United Kingdom share of community GNP (EEC 9) in $1961-25,6 \%$, in $1971-19,4 \%$, in $1974-$ $16,1 \%$, in 1980 under the forecast of 1975 should make only $14 \%[17]$.

In 1976 according to the official data the British economic position and prospects were gloomy [13]. Britain was still running a very substantial trade deficit with Communities partners. Its balance of payments deficit in 1976 was expected to exceed $£ 1,5$ billion. Unemployment was expected to rise to 1,5 million by the end of the year. The trade figures demonstrated that in substantial area of manufacturing Britain was not fully competitive. All this imposed on Britain certain constraints. Which is why Britain went on maintaining that a "developing regional policy which would go some way to equalize differences between the richer and poorer regions - should be an essential part of the evolution of the Community" [13].

There could be no question of Britain being able to join the "snake" on any terms in those circumstances. The British officials argued that inflation rate was still "more than double that of Germany"; the contents of the second stage of the counter inflation policy, let alone its success, were far from assured and Britain still "have a difficult period ahead in which a substantial balance of payments deficit has to be financed. It would therefore be highly risky to commit ourselves to rejoining the "snake", still less on terms which would restrict our freedom to leave it once we have joined" [20]. Therefore, while EMU remained a "valid, though distant, objective", Britain obliged itself not to be committed to any particular method or time-table for achieving it and rejected any commitment to maintain a fixed parity other than in circumstances of their own choosing [13]. The British White Paper of 1975, however, recognized that "closer cooperation between Community countries in the economic and monetary fields is valuable and presents no threat to employment in the United Kingdom" [6]. Furthermore, in 
proper circumstances the UK did not "rule out the possibility that rejoining the "snake" might be a helpful choice at a later stage" [20]. Satisfactory for Britain was the fact that the general view among member Governments was that "the Nine could not in the foreseeable future go much beyond the degree of consultation about economic management in which they now engage" [15].

In the result, the British government concluded to take the following line with its partners. 1. Welcome the fact that Tindemans had recognized that achievement of EMU by 1980 was a wholly unrealistic goal. 2. Welcome the fact that Tindemans had acknowledged the importance of the economic side of EMU. 3. Continue to emphasize view that the real priority was to achieve economic convergence - that was convergence of economic performance, not just economic policy. 4. Acknowledge that Britain had a lot of leeway to make up; and that the responsibility and burden of improving their industrial performance had to rest mainly with Britain. 5. Try discreetly to steer Community discussion on EMU and other economic matters (e.g. unemployment) towards the theme of resource transfers between Member States in the interests of improving lagging industrial performance, reducing unemployment and promoting economic convergence. 6. Emphasize that convergence of economic performance was a precondition for EMU. 7. Advocate transfer of resources from the more prosperous members of the Community (Germany, Benelux and France) to the less prosperous (the UK, Italy and Ireland) as a means both of promoting this convergence and in the meantime of offsetting the balance of payments costs of the CAP and the Community Budget" [20].

\section{Institutional proposals}

Institutional proposals were not of much worry for Britain. Despite of the fact that Tindemans pronounced himself a federalist, he made no proposals of a federalist nature, preferring to "concentrate on improving the operation of the existed institutions which had the approval of the Parliaments of all the Member States" [15] and "whose authority has been reduced" [29]. Strengthening the institutional machinery was all the more necessary since the tasks which the institutions were going to undertake were evidently difficult. From the evidence that the European Community had integrated markets Tindemans concluded that the European Union should have integrated policy. The qualitative change which this vision demanded depended upon the decision-making process that is to say upon the institutions. In Britain thought that the Belgian Prime Minister advocated a reinforcement of the "intergovernmental" faction both within the European Council and the Commission. However, Tindemans made no proposals of intergovernmental nature. He argued: "A return to intergovernmental co-operation would not help to solve European problems. Such co-operation tends to underline the differences of power and interests between our countries and does not meet our collective needs. It is therefore a common institutional machinery which must be reinforced" [29]. That is why, Tindemans stated that while taking decisions on Community matters, the European Council should act in accordance with the forms and procedures prescribed by the Treaties establishing the Communities on super-national nature. This also included majority decisions. From the one hand, mechanism of majority voting decreased the role of a separate national state in decision-making process and weakened the intergovernmental faction, but, from the other hand, it speeded up the decision-making process and made it more effective.

As a primarily task Tindemans suggested to increase Parliament in its powers. For the purpose of this, the European Council had to allocate to the European Parliament the right to propose legislation in order to broaden the powers of this institution. The Council had to undertake to discuss the resolutions submitted to it by Parliament, so that this Assembly was able "to make an effective contribution towards defining common policies" [11].

At the same time Tindemans emphasized an increased role of the Commission as a super-national authority. Under the terms of the Treaty the Commission could considerably influence the determination of common policies by the proposals which it submitted to the Council. In order to give the European Commission increased authority and cohesion Tindemans suggested that the Treaties be amended as follows:

a) the President of the Commission should be appointed by the European Council;

b) the President when appointed should have to appear before the Parliament to make a statement and had his appointment confirmed by vote;

c) the President of the Commission should then appoint his colleagues in consultation with the Council and bearing in mind the number of Commissioners allocated to each country [29].

Later, explaining his proposals Tindemans pointed out that there were at least two schools of thought. In the view of some, the Commission should become the future executive body, in the view of others, a committee of senior civil servants. It was clear that any strengthening of the role of the European Council weakened the Commission. The philosophy of the Treaty of Rome, however, required the Commission to ensure that the European ideal was respected and that the "small" countries were not crushed underfoot. Tindemans, therefore, proposed that the European Council appoint the President of the Commission who was to be endorsed by the European Parliament.

Not to cause a war between the various schools of thought Tindemans suggested that the future President of the European Commission should be appointed by the European Council and that he should choose the members of his team in consultation with the Council. "Precisely by doing so, I accept the role of the Council and also strengthen that of the Commission. It is the standard principle of the Treaty that is being upheld", the Belgian Prime Minister said [11].

The institutional proposals in the Tindemans report were outlined and briefly commented on by the British officials in "as positive a tone as they could". Some of the proposals, however, were new and might have led to protracted 
discussions in the Community. British government wanted to ensure that they were either modified or dropped [18].

Regarding the permission to the Assembly to contribute towards defining common policies, Britain wanted to clarify what sort of resolutions the Assembly would address to the Council. If they contained general political or economic views, of which the Council could simply take note, they would have no great significance. There were two possible developments which Britain wanted to discourage. (1) Tindemans new proposals might have developed into specific legislative proposals coming from the Assembly to the Council. The immediate consequences might have been tolerable for Britain if the Council retained the power of decision, but the longer term effects required careful consideration. (2) Representatives of the Assembly might have hoped to secure some form of joint discussion of their proposals with the Council. This would be time-consuming and complicated the Council's work. The British argued that Assembly had already held wide-ranging debates and could have invited visiting statesmen to speak [18].

The British officials argued that "it would be a mistake to complicate this work by trying to deal at the same time with proposals for new powers" and suggested to see first how the Assembly got on in handling its existing powers (dating from 1 January 1975) on the Budget, and how the conciliation procedure worked keeping in mind the need not to complicate the work of the Council unduly. The proposal of direct elections to the Parliament raised as well important political and practical problems in which Member States were already deeply involved.

On majority voting Britain agreed that the minority should be ready to accept a majority view when no "important national interest" was at stake [18]. The British position on new method of appointing the President and members of the Commission waas highly negative because it could raise a number of problems. For Britain, agreement in the European Council on the President would be desirable, and some degree of consultation between the President-designate and the Member Governments about the other appointments to the Commission could be useful. But, the President "should not acquire a right of initiative in nominating Members of the Commission; and the power of appointment must rest with the Member Governments". The partially modified procedure suggested for 1976, when the President-designate should "help to prepare for the meeting to appoint other Members, but would not have the power to appoint them", appeared to be acceptable for Britain and should be tried out before any more far-reaching change was considered [18].

Emphasizing the intergovernmental approach Britain, however, agreed to consider specific proposals to delegate responsibilities to the Commission within the framework of Community legislation. On the other hand, the British officials had "serious doubts about the more far-reaching change suggested for later years and think the selection Members of the Commission and their appointment must rest with the Member Governments" [18].

In his report Tindemans made proposals related to Human rights protection. In his views the European Council should "instruct the Institutions to consider how best to recognize and protect fundamental rights" and individuals should have the right of appeal to the European Court against acts of an Institution in violation of fundamental rights.

For Britain this proposal needed careful examination. Human rights in Member States were already protected by the Commission and Court of Human Rights in Strasbourg. Fundamental constitutional rights were protected by the Courts of the Member States. Therefore, there was no good case for usurping those existing jurisdictions. Nevertheless, the British officials were recommended to adopt as positive a tone as they could in "commenting on the institutional proposals in general" [15]. Besides, as the British Prime Minister positively stated, the French and the Germans seemed in practice to be approaching the Report in just as unFederalist a spirit.

\section{Conclusions}

Our findings related to the British attitude towards European Union project of 1975 can be summarize as follows. The European Union project of 1975 covered foreign, economic, monetary and social policies as well as institutional matters. We found that the issue of foreign policy was of fundamental importance for construction of the EU in the first half of 1975. The UK did not see European unity as something narrow or inward-looking and emphasized the importance for Britain as well as for the other European countries of vital links with other continents. Common foreign policy could allow Europe make its voice heard on international scale. By putting forward its full economic strength Europe could gain the political influence which it could exert within the United Nations, within the Western Alliance, affecting a lasting détente between East and West; and equally contributing to the solution of the world's North-South problem, to the needs of the developing world. In Britain's view a general détente with the East might open up considerable opportunities for trade with the Eastern Europe since foreign trade in Eastern Europe was under strict political control. For the purpose of this the members of the European Community had to act in common in all the main fields of their external relations whether in foreign policy, security, economic relations or development aid. But, neither could be achieved without consolidating the authority and effectiveness of common institutions, without political obligations being transformed into a legal one which Britain opposed.

Despite of the fact that the British government welcomed Tindemans' foreign policy proposals as forming the basis of a positive contribution towards the search for the outward looking Community, speaking with one voice in the world that Britain had always advocated, the British officials were doubtful whether it was necessary to introduce a legal obligation. It could well be better for Britain to take up L. Tindemans` suggestion in a more pragmatic way by merely intensifying the practices already grown up without seeking a 
juridical basis for them. That is why the UK agreed only to rally to the majority view if it was in a minority on issues arising in these areas where Britain's important national interests were not engaged.

As to suggestions on US-European relations and common EEC policies towards the United States the UK advocated having freedom of actions, especially in the relations with the US and opposed seeking to establish" principles" and write them down on "tablets of stone". There was no scope there for it since Member States' relations with the United States covered such a wide field. By proposing a more binding commitment to reach common policies in very much narrower areas Tindemans "put the cart before the horse". To delegate one of its members to talk to the United States might lead the Nine into the difficulties of coordinating national interests. In Britain's view the Gymnich formula of 1974 whereby the Presidency kept in touch with the Americans was still appropriate.

In the defense matters the British argued that nothing should be done which might endanger in the slightest major requirement of maintaining the complete confidence and support of the US for NATO. Not to worry the Americans Britain suggested that common positions of the Nine on defence matters did not cut across their common responsibilities within NATO or risk impairing the solidarity of the Alliance. In Britain's view the Community had to complement that effort by means of common industrial policy for the defense industries of the Nine.

The second field of activity which embraced economic, monetary and social policies was much less satisfactory for Britain. At the heart of the EU project was Economic and Monetary Union. A plan to achieve Economic and Monetary Union by 1980 implied a transfer of national sovereignty in the economic sphere to Brussels with political repercussions and left little room for maneuver for an individual state. EMU implied a convergence of economic performance, policies and national priorities, which did not exist among Member States, a transfer of resources from richer to poorer Member States, and a transfer of national sovereignty to Brussels to which Britain and some other members of the Community were not ready. So, instead of acceptance of the "snake" mechanism as the main means of achieving economic integration, Britain emphasized economic convergence - that was convergence of economic performance, not just economic policy. Britain tried discreetly to steer Community discussion on EMU and other economic matters (e.g. unemployment) towards the theme of resource transfers from the more prosperous members of the Community (Germany, Benelux and France) to the less prosperous (the UK, Italy and Ireland) as a means both of promoting this convergence and in the meantime of offsetting the balance of payments costs of the CAP and the Community Budget. That is why, Tindemans' suggestions still needed cautious and careful analysis and were unacceptable at least as they stood.

Institutional proposals were not of much worry for Britain. The Tindemans report, as it made no proposals of a federalist nature, marked another stage in the acceptance by the federalists that European Union was not the same thing as a federal system and that any federal structure was a very distant prospect, if indeed it was a prospect at all. In the British views Europe should evolve as fast as the constituent Governments (and their public opinion) wished, but no faster. The UK tried to avoid juridical obligations in decisionmaking process and supported intensify the practices already grown up without seeking a juridical basis for them.

To enhance understanding of the British government's role in implementation or alteration some of the Tindemans proposals in further discussions of European integration issues further research is required.

\section{References}

[1] Chepik, V. N. (2017). A Quiet Revolution of Edward Heath. Vestnik Sankt-Peterburgskogo universiteta. - Saint-Peterburg university. Serious 2. Vol. 62. Issue 4. 2017. P. 855-864.

[2] Conclusions of a Meeting of the Cabinet. (1970). East-West Relations. Oversea Affairs East-West Relations: The GermanRussian Treaty. 3 September, 1970. CAB 128-47. URL: http://www.nationalarchives.gov.uk (accessed 10.09.2018).

[3] Delors, J. (2004). Mémoires. Paris 2004, P. 85. URL: https://doi.org/10.3917/eufor.353.0013 (accessed 20.11.2018).

[4] Dosenrode-Lynge, S. Z. (2002). Political Aspects of the Economic and Monetary Union: The European Challenge. Routledge. 2002, P. 282.

[5] Economic and Monetary Union. (1971). FCO. 30/789 URL: http://www.pro.gov.uk/releases/nyo2001/europe4-al.htm (Accessed 02.02.2004).

[6] EEC White Paper. (1975). Annex A. Degree of Divergence Between the Economic Performance of the United Kingdom and Other Member States. CABINET. 21 March 1975. CAB 129-182. URL: http://www.nationalarchives.gov.uk (accessed 10.09.2018).

[7] Gifford, C. G. (2014). The British State and European Integration: The Politics of Modernisation. London School of Economics and Political Science. ProQuest LLC. 2014. P. 314.

[8] Helm, T. (2016). British Euroscepticism: a brief history. How the UK has struggled to come to terms with continental Europe's political ambitions. URL: https://www.theguardian.com/politics/2016/feb/07/britisheuroscepticism-a-brief-history (accessed 15.12.2018).

[9] Hertogenbosch (1975). Interview with Leo Tindemans on the European union. 27 September 1975 / Documentatie over het 'Rapport Tindemans' inzake de Europese Unie. 1974-1976, 463.

URL: http://www.cvce.eu/obj/interview with leo tindemans on th e_european_union_s_hertogenbosch_27_september_1975-en3c $93 \mathrm{fc} 97-\mathrm{f} 139-43 \mathrm{fo}-\overline{\mathrm{b}} 0 \mathrm{db}-2 \mathrm{ddad} 83 \mathrm{fe} 8 \mathrm{aa} \cdot \mathrm{html} \quad$ (accessed 10.01.2019).

[10] House of Lords Debates. (1976). EEC Summit Conference. 23 June 1976. Vol. 372 cc380-418. URL: https://api.parliament.uk/historichansard/lords/1976/jun/23/eec-summit-conference-december1974 (accessed 10.09.2018). 
[11] Interview with Leo Tindemans published in La Libre Belgique (1976). Tour d'horizon international et européen avec le Premier minister. La Libre Belgique. 16.02.1976, $\mathrm{n}^{\circ} 47$; 93e année. Bruxelles: Edition de la Libre Belgique. P. 1-3. URL: http://www.cvce.eu/obj/interview with leo tindermans publi shed_in_la_libre_belgique_16_fe bruary_1976-en-0eee57980895-4b10-9383-9a551bb3fc41.html (accessed 10.01.2019).

[12] Lee, S. J. (1996). Aspects of British Political History, 1914 1995. Florence, KY, USA: Routledge, 1996. p 283.

[13] Memorandum by the Secretary of State for Foreign and Commonwealth Affairs. (1976). The Tindemans Report Annex. British Objectives in the European Community. Note by officials. CAB 129-188. CABINET. 19 March 1976. URL: http://www.nationalarchives.gov.uk (accessed 10.09.2018).

[14] Memorandum by the Prime Minister. (1971). The European Economic Communities. CABINET. 2 August 1971. CAB 129-158. URL: http://www.nationalarchives.gov.uk (accessed 10.09.2018).

[15] Memorandum by the Secretary of State for Foreign and Commonwealth Affairs. (1976). The Tindemans Report. CAB 129-188. CABINET. 19 March 1976. URL: http://www.nationalarchives.gov.uk (accessed 10.09.2018).

[16] Nielsen-Sikora, J. (2007). The ideas of a European Union and a citizen's Europe: The 1975 Tindenmans report and its impact on today's Europe. European Union Liason Committee of historians Vol. 11. Brussels: Bruylant; Baden-Baden: Nomos; Paris: L.G.D.J., 2007. 408s.

[17] Note by the Secretary of the Cabinet. (1976). British Objectives in the European Community. Annex A. Degree of divergence between the economic performance of the United Kingdom and other member states. 19 March 1976. CAB 129188. URL: http://www.nationalarchives.gov.uk (accessed 10.09.2018).

[18] Note by Officials. (1976). Institutional proposals in the Tindemans report. Annex C. 8 March 1976. CAB 129-188. URL: http://www.nationalarchives.gov.uk (accessed 10.09.2018).

[19] Note by Officials. (Undated). Tindenmans' report on European Union: Foreign policy aspects. Annex A. CAB 129188. CABINET. URL: http://www. nationalarchives.gov.uk (accessed 10.09.2018).

[20] Note by Officials. (1976). Tindenmans 'report: Economic, Monetary and Industrial aspects. Annex B. 9 March 1976. CAB 129-188. URL: http://www.nationalarchives.gov.uk (accessed 10.09.2018).

[21] Nuttall, S. J. (1992). European Political Co-operation. Clarendon Press - Oxford. 1992. P. 342.

[22] Record of Conversation. (1970). Record of Conversation Between the Chancellor of the Duchy of Lancaster and the Luxembourg Prime Minister. Luxembourg: 27 October 1970. CAB 164/771. URL: http://www.pro.gov.uk/releases/nyo2001 (accessed 10.09.2018).
[23] The anti-Tindemans Report (1975). Options For The Left. December 1975, № 57. Brussels: Lambert, John. URL: $\mathrm{http}: / /$ www.cvce.eu/obj/the anti tindemans report december 1975-en-87be272c-1330-47ef-bode7-6e4602 b6c1f 2 .html (accessed 10.01.2019).

[24] The EEC Negotiations. (1971). The EEC Negotiations Strategic Review. 1971. PREM 15/62 URL: http://www. pro.gov.uk/releases/nyo2001/europe1-al.htm (accessed 23.01.2004).

[25] Theis, F. (1976). Durch qualitative Wandlung zur Europäischen Union. Luxemburger Wort. Für Wahrheit und Recht. 08.01.1976, $\mathrm{n}^{\circ}$ 6; 129e année. Luxembourg: Imprimerie Saint-Paul. $\quad$ P. $1 . \quad$ URL: http://www.cvce.eu/obj/through_a_qualitative_transformation to_european_union_from_luxemburger_wort_8 january_197 $\overline{6}$-en-ead050d $\overline{8}-3 \mathrm{ff} 9-\overline{4} 413-\overline{8} \mathrm{ac} 9-055 \mathrm{a} 110 \overline{\mathrm{a}} 2 \mathrm{f} 22 . \overline{\mathrm{htm}}$ (accessed 10.01.2019).

[26] Thomson, G. (1976). Address by George Thomson on the Tindemans Report (Brussels, 1 March 1976) / Archives historiques des Communautes europeennes, Florence, Villa Il Poggiolo. Depots, DEP. Emanuele Gazzo, EG. EG 121. URL: http://www.cvce.eu/obj/address_by_george_thomson_on_the tindemans report brussels 1 march 1976-en-0c8be 6 be06b4-409 $\overline{\mathrm{f}}-\mathrm{bd} 52-11 \mathrm{f} 4 \mathrm{a} 09 \mathrm{~cd} 1 \mathrm{eb} . \mathrm{html}$ (accessed 10.01.2019).

[27] Tindemans, L. (1975). Report on European Union. (The Tindemans Report), 29 December 1975//Hill C., Smith K. E. European Foreign Policy: Key Documents. GBR: Routledge, 2000. P. 122-135.

[28] Tindemans, L. (1976). Statement by Leo Tindemans. 7 January 1976. Bulletin of the European Communities. December 1975, No 12. Luxembourg: Office for official publications of the European Communities. P. 5-7. URL: $\mathrm{http}: / /$ www.cvce.eu/obj/statement_by_leo_tindemans_7_janua ry_1976-end8c13997-f999-492c-bd2c-f2947b0d9a9b.html (accessed 10.01.2019).

[29] Tindemans, L. (1975). European Union. Report to the European Council. Brussels, December, 1975. CABINET. CAB 129-188. URL: http://www.nationalarchives.gov.uk (accessed 10.09.2018).

[30] Tindemans Report. (1976). HC Deb 19 May 1976. Vol. 911 cc1409-121409. URL: https://api.parliament.uk/historichansard/commons/1976/may/19/tindemans-report (accessed 10.09.2018).

[31] Transcript of a conversation. (1970). Transcript of a conversation between the Prime Minister and the President of the United States. June 19, 1970. URL: http://www.pro.gov.uk/releases/nyo2001) (accessed 10.09.2018).

[32] Treaty of Rome. (1957). Treaty Establishing EEC. URL: https://www.ab.gov.tr/.../1957_treaty_establishing_eec.pdf (accessed 15.12.2018). 